
КОМУНІКАТИВНІ СТРАТЕГІЇ ФОРМУВАННЯ ГРАМАТИЧНИХ НАВИЧОК
У КУРСАНТІВ НАДПСУ У ПРОЦЕСІ ВИВЧЕННЯ АНГЛІЙСЬКОЇ МОВИ

\title{
COMMUNICATIVE STRATEGIES FOR DEVELOPING NASBGSU CADETS' GRAMMAR SKILLS IN THE PROCESS OF LEARNING ENGLISH
}

у статті розглядаються комунікативні стратегії орормування граматичних навичок, досліджується потенціал застосування комунікативного підходу до їх форо мування. Здійснено конструктивний аналіз досліджень, які торкаються цього аспекту методології, з метою систематизації стратегічних підходів до вивчення граматики й побудови алгоритму формування граматичних навичок. Проведені розвідки дали змогу дійти висновку, що фрормування граматичних навичок є досі актуальною проблемою. Практика викладацької діяльності показує, що граматика $\epsilon$ матеріальною основою мовлення, без якої неможливо опанувати мову. Однак вивчення граматичних форм на умовно-комунікативному рівні не дає змоги запустити механізм їх автоматизації й підсвідомого вживання в мовленні.

Розглянуто такі стратегії формування граматичних навичок, як використання функціональних можливостей тексту, тематичних завдань і завдань, розрахованих на механізм взаємодії, дискурсивного аналізу текстів, стратегіі зворотного зв'язку між учасниками навчального процесу, компаративного аналізу мовних зразків у мовах оригіналу $і$ перекладу. Використання функціональних можливостей тексту покликане привернути увагу курсантів до об'єкта вивчення й акцентувати контекст його вживання. Тематичні завдання мають на меті вживання певного граматичного аспекту в мовленні й залучення курсантів до особисто значимої взаємодії. Завдання, які розраховані на механізм взаємодії, передбачають спільні дії курсантів у напрямі точного відтворення зразка. Дискурсивно-аналітична стратегія роботи з текстом дає змогу вивчити різні види дискурсу на предмет контекстуального вживання конкретної граматично форми й визначення ії функиій. Стратегія зворотного зв'язку ґрунтується на повтореннях, перепитуваннях і поясненнях, перевірках і підтвердженнях, які застосовуються самими курсантами або ж викладачем для полегшення розуміння складних граматичних структур. Метод компаративного аналізу найкраще працює у групах, які вивчили більшість граматичних аспектів, але продовжують працювати над особливостями їх застосування. Метод передбачає залучення курсантів до власних пояснень граматичних аспектів засобами метамови.

До суттєвих умов опанування граматичними знаннями варто зарахувати: здатність курсанта впізнавати й розуміти граматичне явище, яке вивчається; тренування мовних зразків у характерних для конкретних граматичних явищ ситуаціях; виконання особистісно-значущих тематичних завдань; систематичність опрацювання, тобто дотримання логічного алгоритму вивчення граматичних явищ.
Ключові слова: граматичні навички, фрормування, комунікативний підхід, мовлення, завдання, мовна форма, викладання.

The article focuses on the communicative strat egies for developing grammatical skills, and explores the potential of using a communicative approach to their development. A constructive analysis of the researches concerning this aspect of the methodology has been carried out in order to systematize strategic approaches to grammar study and an algorithm development of grammatical skills formation. The conducted researches bear testimony to the fact that the grammatical skills formation is still an urgent problem, since they provide both formal and functional sides of the grammatical aspect. Our teaching experience shows that grammar is the material basis of speech, without which it is impossible to master the language. However, the study of grammatical forms on the quasi-communicative level does not allow to start the mechanism of their automation and subconscious use in speech.

Strategies for developing grammatical skills are considered. The strategies under study include text enhancement, focused tasks and collaborative tasks, discource-based analysis, interactive feedback between participants in the learning process, contrastive analysis of language samples in the original language and the language of translation.

The text enhancement is intended to draw cadets attention to the object of study and to emphasize the context of its use. Focused tasks are aimed at applying a certain grammatical aspect in speech and involving cadets in a personally meaningful interaction. Collaborative tasks imply cadets' join actions aimed at accurate reproduction of the sample. The discource-based analysis enables cadets to study different types of discourse for contextual use of a particular grammatical form and defining its function. The interactive feedback between participants in the learning process is based on repetition, interrogation and explanation, checks and confirmations applied by the cadets themselves or by the instructor to facilitate understanding of complex grammatical structures. The method of contrastive analysis of language samples in the language of origin and the language of translation works best in groups that have learned the majority of grammatical aspects but continue to work on their specific applications. The method involves cadets' own explanations of grammatical aspects by means of metalanguage. The essential conditions for mastering grammatical knowledge include: cadet's ability to recognize and understand the grammatical phenomenon under study; speech patterns training in specific for selected grammatical phenomena situations; fulfillment of personally-meaningful focused tasks; grammatical error correction tasks; systematic training, i.e. adherence to a logical algorithm for learning them. Key words: grammatical skills, development, communicative approach, speech, tasks, language form, teaching. 
Постановка проблеми у загальному вигляді. Захоплення комунікативним методом навчання іноземних мов, починаючи з 90-х років, значно підірвало роль граматики в навчанні іноземної мови. Йшлося навіть про те, що навчання граматики - не лише безкорисне, а й часом згубне. Проте сучасні дослідження і практика викладання іноземної мови, зокрема для професійних цілей, доводить безпідставність і шкідливість такого забуття. Тому тенденції щодо перегляду і відродження методики викладання граматики знову набувають розвитку.

Викладання граматики в практичному курсі основної іноземної мови для майбутніх офріцерівприкордонників порушує кілька питань: як треба навчати граматики, щоб полегшити і покращити вивчення мови, і якою методикою варто послуговуватися викладачам, щоб забезпечити здатність курсантів практично застосовувати знання 3 граматики в мовленні?

Аналіз останніх досліджень і публікацій. Проблему опанування основ граматичних навичок іншомовного спілкування досліджували такі науковці, як Ю. Пассов (опанування граматичними формами шляхом їх практичного застосування в мовленнєвій діяльності), Н. Скляренко, С. Шатілов (формування рецептивних і репродуктивних граматичних навичок), О. Вовк, Н. Скляренко (особливості інтенсивного навчання граматичної сторони спілкування), Л. Черноватий (організація граматичного матеріалу), Ю. Сердечний (причини недостатнього володіння фрункціонально-граматичними особливостями мовлення), Ж. Нуршаіхова, Г. Пальмер (структурний підхід до викладання граматики), Дж. Лі, П. Колінз (причини граматичної неграмотності в іншомовному мовленні), Дж. Річардз, Р. Репен (принципи викладання граматики) та інші.

Метою статті $€$ систематизація стратегічних підходів до вивчення граматики й побудови алгоритму фрормування граматичних навичок у курсантів Національної академії Державної прикордонної служби України ім. Б. Хмельницького (далі - НАДПСУ) в процесі вивчення англійської мови.

Виділення не вирішених раніше частин загальної проблеми. Тривалий час тривали дебати між прихильниками та противниками щодо необхідності викладання граматики під час вивчення мови. Серед противників необхідності викладання граматики існує переконання, що мову варто вивчати природним шляхом, тобто навчити студентів розмовляти іноземною мовою, принаймні на рівні, необхідному для подальшої роботи, а не шляхом вивчення правил або граматичних конструкцій. Вони вважають, що граматика розвиває лише декларативні знання граматичних структур, а не дискурсивні здатності правильно використовувати їх у мовленні, а також те, що між цими двома знаннями немає зв'язку.
Однак прихильники викладання граматики на заняттях з іноземної мови спростовують це припущення. До причин переоцінювання ролі граматики як невід'ємного компонента вивчення мови вони зараховують те, що візуальне фріксування й усвідомлення мовленнєвих зразків, які вивчаються, відіграють важливу роль в опануванні мови. Крім того, дослідження доводять, що одночасне засвоєння як граматичного, так і лексичного знання $€$ занадто складним завданням, тому спочатку необхідно засвоїти форму на вже відомому лексичному матеріалі, а потім зміст, використовуючи засвоєні граматичні структури. До того ж бажаний рівень мовної грамотності неможливо досягти без усвідомлення граматичних явищ.

Ці розвідки красномовно доводять, що фрормування граматичних навичок $€$ актуальною проблемою. Їх фрормування забезпечує як формальну сторону граматичного аспекту, тобто правильне оформлення граматичної структури згідно з нормами мови; так і фрункціональну використання граматичного явища в мовленні відповідно до комунікативних завдань, і позатим втілює комунікативні можливості граматичних явищ [2, с. 151]. За визначенням Ю. Пасова, граматична навичка $€$ сукупністю автоматизованих дій, що забезпечують адекватне морфолого-синтаксичне офрормлення одиниці мовлення. 3 цього випливає, що правильність висловлювання залежить від знання специфріки граматичних структур і граматика $є$ основою ефективної реалізації комунікативного задуму. Отже, сорормованість або несфрормованість граматичних навичок суттєво впливає на процес комунікації і вимагає комплексного підходу до їх фрормування.

Виклад основного матеріалу. Будь-яка мовленнєва діяльність зумовлена знанням мовного правила і вмінням застосовувати його у своїй практичній діяльності. Отже, мовленнєва діяльність реалізується за правилами конкретної мови, які підлягають вивченню, усвідомленню, розпізнаванню, багаторазовому тренуванню, вживанню в «живому змістовому мовленні» і його автоматизації. Таким чином досягається контекстуалізація конкретного граматичного аспекту та його «вкорінення» в мовленні. Ми погоджуємося з уже відомим і досить слушним алгоритмом вивчення граматичних явищ: презентація, сприйняття структури й її тренування в рецептивно-репродуктивних вправах, розвиток навичок в умовно-комунікативних вправах, застосування навичок у багатоконтекстному мовленні, автоматизація навичок в усному мовленні, підсвідоме застосування структури.

Граматику неможливо відірвати від мовлення, бо вона диктує правила, як змінювати слова i поєднувати їх у реченні, надає нашим думкам фрорму, тобто матеріалізує їх. Отже, граматику можна вважати матеріальною основою мовлення, 
без якої неможливо опанувати мову. Тому за будьякого методу або прийому навчання мови необхідно брати до уваги граматичний аспект. Якби наш лінгвістичний досвід не був упорядкований певною системою, яку називають граматикою, то ми б «нагадували папуг», які можуть повторювати і розуміти лише те, що почули [4, с. 107]. Однак опора на граматичні аспекти може мати різноманітні фрорми і зміст залежно від особливостей матеріалу, який вивчається, його складності, схожості або несхожості з аналогом рідної мови $[1$, с. 18$]$.

Отже, як навчати курсантів граматики з метою підвищення їхньої мовної грамотності? Беручи до уваги той фракт, що граматика - це матеріальна основа мовлення, себто комунікація ґрунтується і на граматичних навичках, тому серед низки стратегій ми зупинимося на комунікативних. Адже саме вони дають змогу опанувати граматичні структури на рівні практичних умінь і навичок, «запустити» механізм їх автоматизації й підсвідомого вживання в мовленні.

Розглянемо використання фрункціональних можливостей тексту (text enhancement). Вивчення граматичного аспекту в тексті як основної комунікативної одиниці, яка дає змогу шляхом читання або слухання з подальшим коментуванням, перекладом, обговоренням вивчити новий граматичний матеріал, навчитись ідентифікувати, усвідомлювати значення й відтворювати цільовий граматичний аспект у комунікативній ситуації на основі тексту, спрямоване на те, щоб привернути увагу курсанта до певної граматичної фрорми. Виділення певного граматичного аспекту може проявлятися шляхом підкреслення, друкування цільової структури великими літерами, виділення курсивом, жирним шрифртом тощо. Таким чином, об'єкт вивчення не залишиться без уваги. Іншим шляхом виділення може стати завдання, яке передбачає знаходження відповідної форми, її підкреслювання й формулювання правила.

Такий шлях може здатися довгим або мати ризик спотворити справжнє значення цільового френомена й спричинити стійкі помилки в мовленні, однак він має більше переваг, ніж недоліків. Серед переваг: краще розуміння і запам'ятовування матеріалу, що вивчається; стимулювання самостійного мовного спостереження й усвідомлення цільової структури; розвиток здогадки за контекстом; реалізація принципів проблемного навчання.

Тематичні завдання (focused tasks) у вивченні іноземної мови завжди мали широку підтримку, увага яких зосереджувалася головним чином на комунікативній складовій вивчення мови. Спеціально створені завдання сприяють вживанню певного граматичного аспекту й одночасно залишаються комунікативними завдяки тому, що курсанти залучаються до особисто значимої взаємодії, яка спрямована на вивчення певної мовної форми.
До таких завдань зараховують: завдання, які передбачають використання окреслених структур, тренувальні завдання, завдання на усвідомлення й актуалізацію. Перші передбачають виконання комунікативного завдання шляхом застосування окреслених граматичних структур. Другі створюються 3 метою акцентування уваги курсантів і тренування цільового граматичного явища в ретельно спланованій подачі. Зазвичай вони можуть включати завдання на реагування у відповідь на запитання або спонукальне речення, підготовку Wh-запитань із метою інтерв'ювання відомих людей, потенційних порушників кордону або анкетування одногрупників за певною тематикою.

Завдання на усвідомлення й актуалізацію конкретної мовної форми мають на меті залучення курсантів до обговорення певних граматичних структур, завдяки чому граматична фрорма трансформується у зміст завдання. Вони також стимулюють курсантів до маніпулювання структурою, «гри» 3 нею 3 різним лексичним наповненням, створення правил для неї. У цьому сенсі завдання $\epsilon$ універсальною фрормою дієвості навчального процесу і слугує способом організації засобів, їх презентації й мотивації мовленнєвої діяльності, а також умовою фрормування мовних навичок і мовленнєвих умінь [3].

Тематичне завдання як одиниця навчання не лише моделює комунікативну ситуацію, але й зберігає основні якості комунікації, що дає змогу використовувати його як стимул до мовленнєвої співпраці. Адже бажання спілкуватися з'являється за реальної причини, інтенції, що знаходяться в колі інтересів комунікантів. Крім того, зміна предмета розмови, умов спілкування, співрозмовника створює елемент новизни, а це означає відмову від «зазубрювання» окремих структур, діалогів, текстів, виконання однотипних вправ тощо. Тематичні завдання за рахунок постійного оновлення розвивають еврістичність і продуктивність як мовленнєвих умінь так і мовних навичок, які перетворюються в так би мовити «побічний продукт» цієї діяльності. Разом із тим прямих вказівок щодо вивчення граматичних структур курсанти не отримують.

Завдання, розраховані на механізм взаємодії (collaborative tasks), також мають гарний потенціал у тренуванні й актуалізації граматичних фрорм. Головною вимогою до таких завдань $€$ правильно поставлена мета, зокрема точне відтворення зразка. Прикладом такого завдання є граматичний диктант. Курсанти прослуховують текст і записують слова або вирази. Запис може здійснюватися двома шляхами: під час самого диктанту або після нього. Після такої підготовчої роботи курсанти працюють у групах, поєднуючи свої записи, вони відновлюють текст близько до його змісту. До прикладу, ілюстративні ребуси, так звані завдання«джигсо» мають схожу мету - зусиллями учасни- 
ків групи скласти в єдине ціле картинку, історію 3 картинок у поєднанні з вербальним доповненням або без нього та описати, використовуючи цільові граматичні форми. Однак, за нашими спостереженнями, граматичний диктант менш часозатратний у підготовці і краще працює на мету.

Дискурсивний аналіз (discourse-based tasks). Дискурсивно-аналітична стратегія роботи 3 текстом - ще один шлях до розуміння і вивчення граматики. 3 одного боку, це можливість вивчення різних видів дискурсу (автентичного або спрощеного) на предмет контекстуального вживання конкретної граматичної фооми; з іншого - визначення її фрункцій. Звичайно, деякі складні граматичні явища, наприклад, часові фрорми, потребують пояснень, однак їх ізольоване вивчення без усвідомлення синтаксичних і прагматичних фрункцій, видається нам неефективним.

Граматичні структури, які відпрацьовуються на окремих реченнях поза межами контексту, часто залишаються на рівні механічного запам'ятовування правила, тобто такий підхід до вивчення граматичного явища може призвести до того, що граматична навичка існує ніби сама по собі, за межами мовленнєвих умінь, які фрормуються. Інколи ми маємо справу 3 досвідом, коли курсанти добре пам'ятають мовні правила, однак вони не допомагають їм у реальному мовленні, що призводить до значних граматичних помилок. Дедуктивні пояснення граматичних правил, відірвані від ситуації спілкування тренувальні вправи можуть бути досить правдоподібною причиною мовних проблем у мовленні [7]. За нездатність допомогти курсантам розвинути навички використання граматичних фрорм у спілкуванні цей підхід піддавали критиці й інші науковці [5]. Доведення не потребує і те припущення, що викладання граматики не є самоціллю, а засобом для використання мови у спілкуванні, отже, викладання граматики варто здійснювати не ізольовано, а в інтеграції чотирьох мовних навичок [6; 8]. Тому відчутного результату в навчальному процесі можна досягнути шляхом поєднання механічного запам'ятовування правил, мовленнєвих зразків й їх усвідомленого використання в певних ситуаціях у процесі виконання навчальних завдань.

Стратегія зворотного зв'язку (interactional feedback strategy) передбачає повторення, перепитування і пояснення, перевірку і підтвердження, які застосовуються самими курсантами або ж викладачем для полегшення розуміння складних граматичних аспектів. Така взаємодія акцентує увагу курсантів імпліцитно й експліцитно на тих граматичних явищах, які вивчаються. Ця стратегія досить ефективна у виправленні помилок один одного. Курсанти отримують завдання прослухати повідомлення/діалог одногрупників і занотувати наявні помилки. Таке завдання не лише акцентує їхню увагу на конкретному матеріалі, але й дає змогу виявляти цільові граматичні структури.

Однак така стратегія може стосуватися не лише фрорми, але й змісту. Так, дискурсивні стратегії змісту застосовуються для корегування проблем у спілкуванні; що ж стосується дискурсивних стратегій форми, то вони призначені для виправлення граматичних помилок.

Застосування перекладу є проявом толерантності до рідної мови, з цієї причини переклад часто виступаєякміжкультурнакомунікація. Врешті-решт, переклад сприяє усвідомленню схожих і відмінних явищ у мовах оригіналу і перекладу, тому може налагоджувати міжкультурне взаєморозуміння. Ми переконані, що компаративний аналіз перекладу (contrastive analysis) мовних зразків у мовах оригіналу і перекладу сприяє точнішому розумінню i, як результат, поглибленню знань граматики.

Загалом більшість теорій, представлених у літературі, розглядають переклад як доповнення до інших методів та підходів, що використовуються в навчанні мови. Вони розглядають переклад як інструмент, що допомагає курсантам опанувати складні граматичні структури або вивчити лексику. Тому, хочєдеякіемпіричнідоказицінностіперекладу у вивченні мови, він не може замінити всі засоби викладання мови, особливо ті, які орієнтовані на комунікативні навички та вільне володіння мовою.

Наше дослідження, яке проводилося на базі кафедри перекладу з курсантами спеціальності 035 Філологія, показало, що переклад однозначно покращив певні аспекти їхньої граматичної обізнаності під час тестування. Саме тому ми вважаємо, що компаративний аналіз перекладу найкраще використовувати 3 курсантами 3 рівнем Intermediate і вище, оскільки переклад передбачає навчальну діяльність із пасивним або новим мовним словником. Окрім того, використання компаративного аналізу перекладу вимагає ретельної адаптації метамови курсантів для порівняння мов оригіналу і перекладу. Переклад найкраще працює в групах, які вивчили більшість граматичних аспектів, але продовжують працювати над особливостями їх застосування. Важливу роль у цьому процесі відіграє добре володіння обома мовами викладачем, який здатний пояснити особливості граматики обох мов курсантам.

Давно забутий граматико-перекладний метод, який мало приділяв увагу опануванню мови, живому спілкуванню, бо його основною метою залишалося вивчення правил та розуміння конструкцій, не має нічого спільного з компаративним аналізом перекладу, оскільки останній не лише демонструє, як «мова працює», але й «мову в дії» шляхом залучення курсантів до власних пояснень засобами метамови.

Наш досвід викладання практики мови показав, що застосування перекладу сприяє кращому 
розумінню вживання часових фрорм дієслів, фрразових дієслів, розпізнаванню фральшивих друзів перекладачів, впорядкованому структуруванню речень, що є доказом актуальності використання перекладу у викладанні мови. На наше переконання, переклад може і повинен мати місце у викладанні мови, тобто бути одним із багатьох інструментів викладання мови й покращення знань граматики зокрема.

Висновки. Незважаючи на тривалі дискусії щодо методів навчання граматики та відсутність єдиного підходу до методики вивчення іноземної мови, практика показала, що до суттєвих умов опанування граматичними знаннями варто зарахувати: здатність курсанта впізнавати й розуміти граматичне явище, яке вивчається; тренування у характерних для конкретних граматичних явищ ситуаціях; виконання особистісно значущих цільових завдань; систематичність опрацювання, адже спонтанне вживання граматичних фрорм $€$ не миттєвим результатом, а процесом, який вимагає часу. Рух до майстерного опанування, вільного використання граматичних фрорм у мовленні займає певний час, і для кожного курсанта він різний. Однак не зовсім зрозуміло, наскільки впливають згадані нами стратегічні підходи до вивчення граматики на точність спонтанного мовлення курсантів. Ця проблема становитиме предмет нашої подальшої розвідки.

\section{БІБЛІОГРАФІЧНИЙ СПИСОК:}

1. Конышева А.В. Современные методы обучения английскому языку. Изд. 2-е, стереотип. Минск : ТетраСистемс, 2004. 176 с.

2. Пассов Е.И. Основы коммуникативной методики обучения иноязычному общению. Москва : Русский язык, 1989. 276 с.

3. Пассов Е.И., Кузовлев В. П., Кузовлева Н.Е., Царькова В.Б. Мастерство и личность учителя: $\mathrm{Ha}$ примере деятельности учителя иностранного языка. 2-е изд., испр. и доп. Москва : ФЛИНТА, Наука, 2001. $240 \mathrm{c}$

4. Щерба Л.В. Языковая система и речевая деятельность. Изд.4 URSS. Москва : Едиториал УРСC, 2004. $432 \mathrm{c}$

5. Jean, G., \& Simard, D. Grammar Teaching and Learning in L2: Necessary, but Boring? Foreign Language Annals. 2011. № 44. Pp. 467-494. https://doi.org/10.1111/j.1944-9720.2011.01143.x.

6. Lee, J.F.K. Enriching Short Stories through Processes. A Functional Approach. System. 2016. № 58. Pp. 112-126. https://doi.org/10.1016/j.system. 2016.03.012.

7. Lee, J.F.K., \& Collins, P. English grammar: An investigation of Hong Kong ESL books. The Hong Kong Journal of Applied Linguistics. 2009. № 11. Pp. 51-70.

8. Richards, J.C., \& Reppen, R. 12 Principles of Grammar Instruction. E. Hinkel (Ed.), Teaching English Grammar to Speakers of Other Languages. New York, NY : Routledge. 2016. Pp. 151-170. 